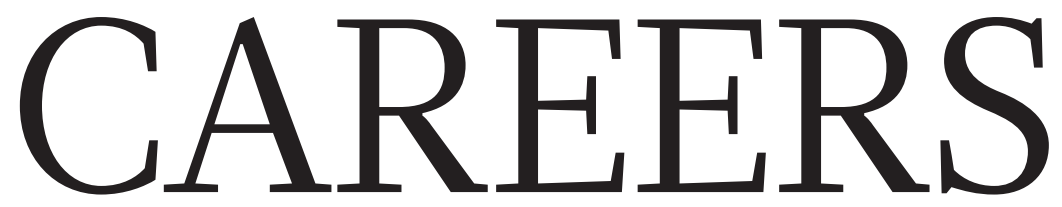

SPEAK OUT Advocate for science in the face of funding cuts $\mathbf{p . 4 2 7}$

BLOG Personal stories and careers counsel http://blogs.nature.com/naturejobs
NATUREJOBS For the latest career

listings and advice www.naturejobs.com

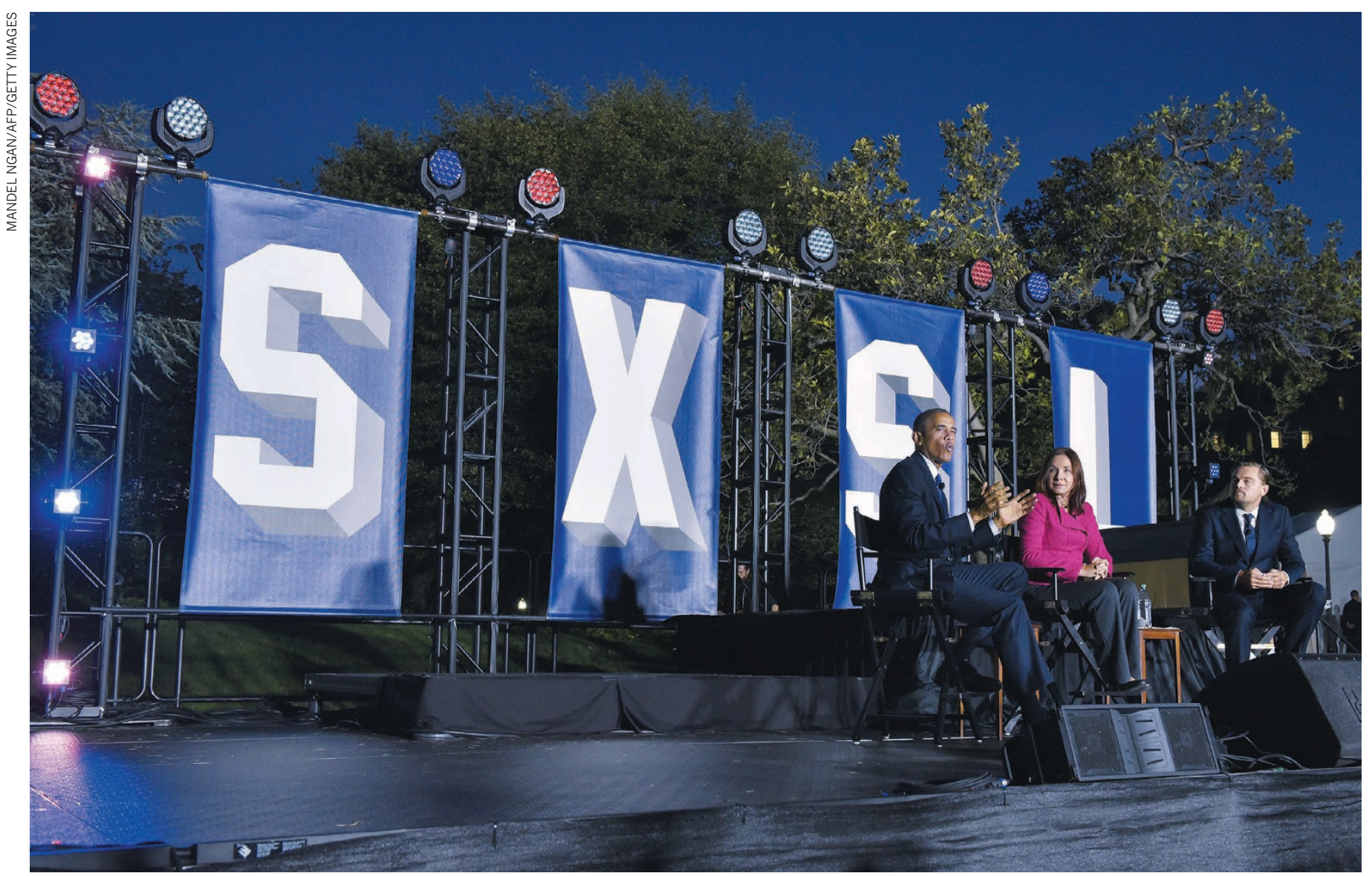

Climate scientist Katharine Hayhoe with US President Barack Obama and actor Leo DiCaprio at the White House South by South Lawn Festival last October.

\title{
COMMUNICATION
}

\section{Post-truth predicaments}

\section{How can scientists get through to a public that's seemingly indifferent to objective facts?}

The term 'post-truth' is now a mainstay of political discourse, its use firmly estab-

lished in any analysis of the European Union referendum result and the outcome of the US presidential election. Academics already struggle to communicate their research findings to the broader society - a problem that is likely to be exacerbated if the public is happy to disregard facts.

As president-elect Donald Trump prepares to take office, how should scientists negotiate this new world order, in which objective facts and evidence can be lost in the noise generated by direct appeals to emotion, sentiment and deeply held personal beliefs? How can they best engage with the public and serve as a voice for science? Nature asked three experts for their views on how to redress the balance.

\section{KATHARINE HAYHOE Share solutions}

Katharine Hayhoe is associate professor in the Department of Political Science and director of the Climate Science Center at Texas Tech University, Lubbock. She is an evangelical Christian and a climate-change scientist in a state whose governor,

Greg Abbott, is vociferously sceptical about global warming. Abbott's is not a lone voice: according to the 2013 Yale Project on Climate Change Communication, only 44\% of Texans polled think that such warming is mostly caused by human activity.

Roughly $75 \%$ of people in the United States belong to a faith tradition. There isn't any major world religion that doesn't have values of stewardship or caring for those less fortunate than ourselves. We may be divided by 
race, nationality or ethnicity, but we share one planet.

I read the social-science literature regularly to better understand what people respond to. I am a living experiment: whenever I read new recommendations on how to communicate science more effectively, I try them out immediately. Some scientists still think that if we simply give people enough information, they will change their minds. That might work for some scientists, but it won't necessarily work for the general population.

I've found the best approach is to try to connect locally and regionally. Make yourself available to the Rotary Club, senior-citizens' centre, book clubs, churches, local schools or community organizations.

In going out to your community, you are serving as an ambassador for your institution - which, you can argue, builds the university's reputation and brand. There is a continuum of public engagement. At one end is a strict focus on laboratory-based research; at the other, the focus is on advocating for specific policy solutions. What we as scientists choose to do, and where we fall on that spectrum, is very personal. It's based on what we know, what we feel is important, how urgent we think the problem is and what we feel we can say at that time. Each of us should constantly and deliberately think about where on that continuum we want to be, and should be.

If you speak at one venue and people respond well to you, the word will spread and you will get more offers to speak. By putting yourself in uncomfortable situations not hostile, but outside your comfort zone - you can see amazing change. Several years ago, I was invited to give a keynote address at the American Scientific Affiliation, an organization of scientists who are Christians. A biologist who was involved in the creation/evolution argument misinterpreted what I said about the agreement on the science and wrote a very critical blog piece about me in a conservative newsletter. When I read it, I got in touch with her and asked her if we could talk. We cleared up the misunderstanding and she invited me to write an essay for the American Institute for Technology and Science Education, an organization that had never published anything in support of climate change before.

Pinpoint the values that people already have and that you can identify with. Is there a shared concern about water, energy, air quality, national security or the economy?

After you've bonded and connected with that audience, don't begin or end with science. People are interested in science, but if you're talking about climate change, you have to connect it to something that matters to them. Keep the message clear, uncluttered and uncomplicated. End with solutions and suggestions for actions to take, and offer hope. Fear paralyses us. Hope is what keeps us going.

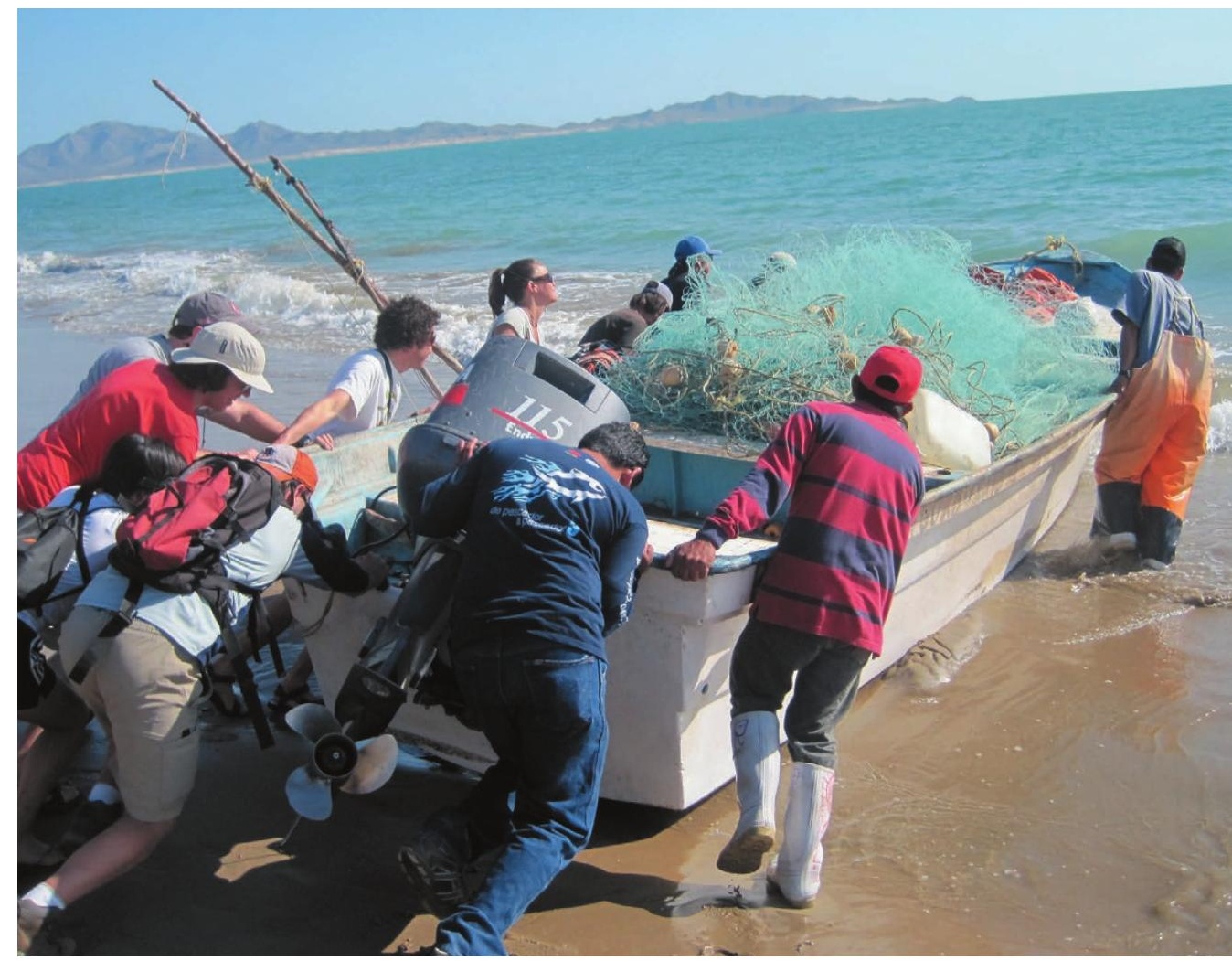

Xavier Basurto and some of his students put to sea on a reef-monitoring trip with Mexican fishermen.

\section{XAVIER BASURTO Bridge divides}

Xavier Basurto is associate professor of sustainability science at Duke University Marine Laboratory in Beaufort, North Carolina. As a social scientist, he studies how groups cooperate and act successfully for the common good. His research brings him into contact with fishermen in Mexico, where he leaves behind the trappings of academia to foster collaboration between different groups.

If you come from an angle of 'science is the truth - you just don't understand the facts', people will not be willing to listen to you. They will find that angle offensive. You need to speak in such a way that people are willing to listen. To do that, it's important to acknowledge that there are many ways of knowing or learning. Humans are not always rational, and we tend to portray ourselves as much more rational than we are. The US election results were surprising because many didn't see them as rational. Incorporating social science into physical and biological sciences is one way to bridge divides in understanding between scientists and non-scientists.

Engaging with your local community gives people a way of listening to who you are instead of focusing on you as an academic. Rather than seeing you as 'the scientist', they might see you as 'the neighbour' and hear your perspective, rather than feeling like 'the scientist is trying to impose his truth on us'.

I teach about governance of the commons: the resources we all depend on, such as fish, forests or clean air. I invited the mayor of Beaufort, a small coastal town, to speak to my class. He said it's really shocking how the same few people participate in decision-making processes that affect everyone. Scientists, too, need to engage to understand how society works.

I'm also part of a research effort involving a conservation group based in Mexico and a confederation of Mexican fishing cooperatives comprising 11,000 fishers. The long-term goal is to improve fishing practices at the national scale as well as the health of reefs.

I realized that Mexico is classist and that people who make a living from small-scale fishing are among the lowest classes. They are also often vilified by environmentalists for depleting the oceans of fish, but the fishermen I work with have established their own protected reserves: no-fishing areas that they have set aside to rebuild fish populations.

I've been able to break the barriers between us by relating to the fishermen personally, rather than as a scientist. I tell them I want to learn how they fish - and when I joined them on a recent trip to monitor reefs that they had left unfished for at least five years, they shared their excitement that the reef was doing better.

Because I worked with the fishermen to co-produce research, we are gaining a better understanding about the effects of these protected areas on communities. They now feel 
that they have a seat at the decision-making table that they didn't have before. Successful conservation in the future will engage with communities in this kind of way.

\section{DOMINIQUE BROSSARD Show that you care}

Dominique Brossard is professor of lifesciences communication at the University of Wisconsin-Madison, where she studies public perceptions of issues such as genetically modified food. She has taken part in two Arthur M. Sackler colloquia on the science of science communication, and contributed to the resulting publications from the National Academy of Sciences.

It is important to know that science communication can backfire - particularly when you're talking about controversial issues, where there is a lot at stake because of ethical, social or legal implications. As a result, science can trigger emotional, value-laden reactions from different groups. Therefore, personal feelings come into play when discussing specific scientific issues - from stem cells and genetic engineering to climate change.

Science can be politicized. And that's OK. That is the reality and it's complicated. The things that we find important as scientists are often not the things that most people care about. We need to realize that it's often impossible to change views when they are entrenched. It's most important to seek middle ground. You are not going to convince people who hold extreme beliefs, but you can try to find a space where you can stand together.

The most powerful way to engage audiences is at the grass-roots level; yet on social media, academics often exist in an echo chamber with like-minded followers. So, if you use social media, try to connect with people who think differently from you.

The same goes for writing opinion pieces. Think about your audience, and how you might frame a piece for The New York Times, compared with how you would pitch the same piece for, say, the Milwaukee Journal Sentinel, a regional Wisconsin newspaper.

Think about ways to frame your insights, taking the psychology of risk into account. For example, in my experience, people are much more receptive to public-health issues than they are to environmental ones, such as flooding in Indonesia or endangered polar bears, because public health is more relevant to their lives.

\section{INTERVIEWS BY VIRGINIA GEWIN}

These interviews have been edited for length and clarity.

\section{TURNING POINT}

Advocacy ambassador

Karen Ring is a stem-cell researcher turned website and social-media manager for the California Institute for Regenerative Medicine (CIRM) in Oakland. As the threat of cuts to science funding sweeps the globe, she is encouraging scientists to advocate for their research.

\section{What was your reaction to the election of Donald Trump as US president?}

I started to read articles about what it would mean for the future of science. I found some of his pre-election comments about science troubling, including criticism of the US National Institutes of Health and his belief that climate change is a hoax. This seemed like a wake-up call for the scientific community. I tweeted, "Now more than ever \#scientists need to speak out about the importance of funding scientific research! Share hashtag \#ImWithScience."

\section{How did people respond?}

The post has been re-tweeted hundreds of times. In October 2016, some colleagues and I started an online @SciParty group to discuss how scientists can do public outreach better. But after the election, we realized that we have to find better ways to connect with people who either don't understand science or are sceptical of it.

\section{What happened with the first @SciParty exchange after the election?}

We discussed what the Trump presidency might mean for US science communication and funding. We also discussed the potential for integrating science-communication training into graduate programmes. One participant suggested that scientists listen more and talk less. Scientists often get caught up in how exciting their research is to them, but forget the big picture. We need to tailor communications to specific audiences.

\section{Did people from outside the United States participate?}

Yes. Funding cuts are happening all over the world. We had people from Evidence for Democracy, a Canadian organization established during former Prime Minister Steven Harper's tenure. They suggested that it's important to be political without being partisan. We're all working towards the same thing - the funding necessary to maintain scientific progress.

What topics will @SciParty tackle in future? Upcoming parties will focus on public

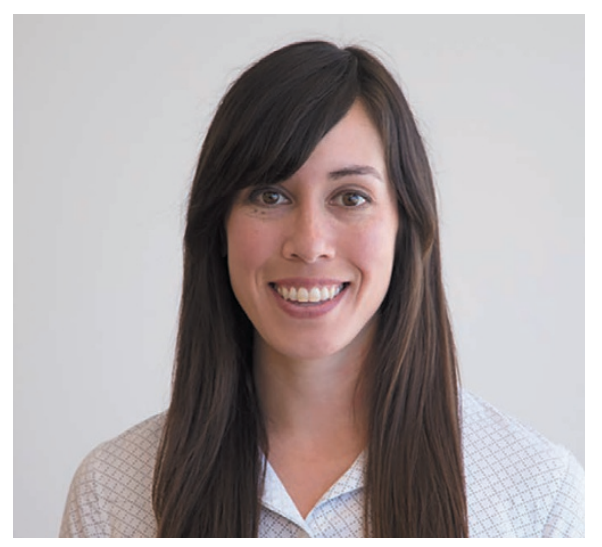

sentiment about climate change and animal biotechnology. We want to intermix topics focused on how to improve science communication with discussions that concentrate on a particular area of science.

\section{What do scientists want to know most during} these discussions?

Mainly, how to improve science communication. People are interested in how to share science through different avenues, such as blogs, art and videos. Many participants have stressed coming up with a mission statement to make sure there is a concrete goal for efforts.

Are you finding synergies with other groups on social media?

Yes, we are trying to collaborate with others to share our audiences and get to know how we can help each other through Twitter and Instagram. There are groups such as @IAmSciArt, @realscientists and@womenofsci.

Do stem-cell scientists have specific concerns? A lot of researchers don't know what to expect. Trump hasn't spoken a lot about his sciencefunding plans, but his past statements are not encouraging. Every state is different. California is lucky. When former President George W. Bush banned federal funding for embryonic stem-cell research in 2004, the CIRM formed, with US $\$ 3$ billion in funding. We won't be affected if there is another federal-funding ban on embryonic stem-cell research. But that's not the case for other states. And there are many others that do important research and would be affected. It's important for scientists to speak out, get involved and help to motivate the incoming administration.

\section{INTERVIEW BY VIRGINIA GEWIN}

This interview has been edited for length and clarity.

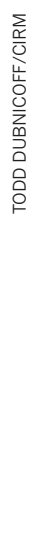

, n 